\title{
Contemporary Geopoetics in the Context of the Formation of a New Geospatial Discourse
}

\author{
Vladimir Gennadyevich Bogomyakov \\ Tyumen State University, Russia
}

Received August 28, 2016; Revised November 30, 2016; Accepted December 05, 2016; Published January 14, 2017

\begin{abstract}
Currently, the geospatial discourse is rapidly changing. This is caused by the search for identity, people's attempts to understand themselves and the space where they live in a new global and universal context. Geopoetics as a semantic field between poetry, philosophy and science, a method of space poetization, an attempt to create a particular language associated with the admiration of landscape, takes a special place among the areas of non-traditional geography, appearing in the conditions of a "spatial turn" in social sciences and humanities. The article considers some geopoetical projects in which the author participated, and concludes that they represent an important trend in the formation of a new geospatial discourse. All of them are not based on meta-narratives, imply the admiration of landscape and empathy for it; they often gravitate toward the performance, happening and street-art.
\end{abstract}

Keywords: geospatial discourse, geopolitics, geopoetics, landscape.

\section{Introduction}

Currently, there is a rapid change in the geospatial discourse associated with the search for identity in every corner of the modern world, people's attempts to comprehend the space of their existence in a new global and universal context. The classical geopolitics with its primitive metaphysics and social-darwinistic methodology, explaining the space as a structure, motivating and defining policies of the countries that are concerned about the expansion of the living space [1, pp. 69-70], is being replaced by such disciplines as cultural geography [2-3], geosophy, existential geography, cognitive geography, psychogeography [4] and geopoetics, etc. This occurs against the background of the so-called "spatial turn" in the social sciences and humanities. It has approved the point of view that we cannot speak about human life and human societies independently of both the human living space and the topology of the places of residence, etc.

Despite the significant differences between these disciplines, there is something in common that unites them - this is a man's attempt to find his place on earth; a place of a true human importance not only as geography of place, but also as "intellectual geography" [5, p. 124] that prescribes symbolic models forming the cognitive and emotional experience of a person. This is also an understanding of the fact that we all live in palimpsests of multiple places. It means that

\footnotetext{
(c) AesthetixMS 2016. This Open Access article is published under a Creative Commons Attribution Non-Commercial 4.0 International License (http://creativecommons.org/licenses/by-nc/4.o/), which permits non-commercial re-use, distribution, and reproduction in any medium, provided the original work is properly cited. For citation use the DOI. For commercial re-use, please contact editor@rupkatha.com.
} 
every place is reinterpreted endlessly, rethought, and endowed with new meanings formed of the elements of the old myth, the structure of which is also endlessly transformed [6]. New disciplines forming the geospatial discourse are focused not on the power or administrative structures, but on the "other" and something "excessive" that reveals to a man the highest sense [7] and makes the space a place full of life and freedom, but not a place of controlled existence. Functionality and utilitarianism in relation to the space give way to the geographical imagination, ecstasy of space perception, admiration of landscapes, etc.

Geopoetics as a special semantic field between poetry, philosophy and science, a method of space poetization, an attempt to create a particular language associated with the admiration of the landscape, takes a special place among the areas of non-traditional geography. Geopoetics tends to be creative geography, differentiating in space cultural, not political processes. In geopoetics, the hidden is found as a result of correlating spiritual cartography with external cartography that defines a measure of reality poetization in the process of naming the unnamed spaces, creating new contexts structuring the human universe. In geopoetics, a "collective excitation" takes place, when the participants in the general movement obtain skills of communication with objects and places incurring a feeling of novelty, surprise and maybe even something miraculous. Kenneth White is a founder of geopoetics. In our country geopoetics is developed by Sid, who interprets it as a project activity aimed at creating and changing various territorial myths. I. Sid considers geopoetics (poieticos means creative) as a new humanitarian discipline aimed at investigating the growing influence of cultural and, above all, creative phenomena on the structuring of the human universe [8].

\section{METHOD}

This article discusses some of the projects of recent years, in which the author took part and which, according to the author, may be interpreted as different forms of modern geopoetics. It appears that they may illustrate the search for the new relationship between man and space and participate in the formation of a new geospatial discourse in a certain way. For the analysis of these projects, an ideographic method and a method of generalization of documentary materials have been used (since the experience of the new relationship with the space has been recorded in print and electronic media, as well as in the original reports and travelogues).

\section{RESULTS}

In 2012 during the festival "White Nights in Perm", the "Poetic Guide for Cultural Alliance Cities" was published. The book contains poems of almost eighty poets from more than twenty Russian cities. In addition to the poems on different cities, the book contains prose notes on the places of power, which the authors considered possible to name and describe. Apparently, a concept "a place of power" first appeared in the works of Carlos Castaneda. Currently, it is also widely used out of the mystical or occult context. A place of power is often called a place where a person experiences a burst of energy, joy and positive emotions.

When we read the description of the places of power in the "Poetic Guide", we can see that they do not have a universal meaning: these are night roofs of Yakutsk blocks of flats; an old shop known only to the long-term residents, reminding of the sixties of the last century; these are forgotten narrow-gauge lines; these are hills and ravines evoking childhood memories; for the poet Ivanhoe this was his favorite sofa. According to Zinovy Zinnik, this is a kind of internal 
cartography that emerges in the mind of each of us since childhood as a kind of a net of parallels and meridians with a center in one's own home. We try to find a place closer to our specific internal cartography... We are trying to combine this nostalgic geography with the reality around us. Zinovy Zinnik suggests that a degree of displacement of these two geographies is a measure of reality poetization [9].

Pages of the "Poetic Guide" are full of thoughts, images and symbols that are largely "wild", not wrapped in a familiar psycho-socio-cultural cover and cannot be easily deciphered. According to Kenneth White, this is the spiritual cartography which involves not only the "in-growth into the soil", but also a continuous search for the relationship with the world; with its energies, rhythms and forms. In the texts of the authors of the "Poetic Guide" such known cities as Kirov, Krasnoyarsk, Nizhny Novgorod are suddenly revealed before us as unknown, undescribed and unnamed spaces. According to, for example, Alexander Vavilov, this is when occurs "Sverdlovsk, which should not be called Yekaterinburg and not affixed on the refrigerator as a magnet souvenir" [10].

In our opinion, the "Poetic Guide" implies, on the one hand, an expression, and, on the other hand, the participation in the creation of what is called "geopoezis" in modern geopoetics. According to Sid, geopoezis is the most significant trend found in the contemporary sociocultural life, which can be interpreted as a cultural self-determination of the territories. This process occurs without any direct and often even an indirect connection with the ethnic-national public-political self-determination (and never coincides with it geographically). Moreover, sometimes it occurs contrary to it. The geopoezis is characterized by the actual nonprogrammability of its result; this process goes on nonlinearly, as if in constant self-knowledge and self-negation, self-assertion, and even discursively "obtained" statements of the project objectives do not ultimately coincide with the actual course of events. I. Sid explains that this certainly refers to the creative search by a system for itself, this process goes on at some transpersonal level, where social-psychological, historical-cultural, political-economic, landscapegeographical and, of course, metaphysical factors interact in an unpredictable way [8].

While reading the "Poetic Guide", the ontological antinomy "geopolitics - geopoetics" is clearly understood; politics is the matter of geopolitics, while creativity and poetry are the matter of geopoetics. Geopoetics is a creative geography, creatable geography and geography of creativity; the work on the formation of a geographically differentiated body of culture. City myths and legends structure the human universe in a special way, assigning events and cultural facts a specific geopoetic meaning, even to the detriment of historical accuracy. Thus, Anvil Kasimov wrote that in 1943, by force of the old habit, Kazimir Malevich crossed the Izhevsk pond and drowned (in fact, Malevich died from cancer in 1935 in Leningrad and was cremated in the suprematic coffin).

Geography of imagination suggests something fabulous, which, as the "other" and "excessive", is perceived by the authors of the "Poetic Guide" as moments of real life and freedom. Larisa Orekhova told about the stone elk near Izhevsk, to which elks come each spring. Rosariya Karimova wrote about a sacred forest near Khanty-Mansiysk, "a forest on the periphery between the city and the miracle" [11]. Legendary routes of buses and trams; ravines, where the abandoned villages are gradually going under the ground; obelisks on the border of Europe and Asia, the Urals and Siberia, and, of course, terrible places associated with pain and blood. And even here "an abandoned hospital in the city center causes an energetic remission more symptomatically than a pathetic church at the place of the execution of the royal family, although both buildings are on blood" [12]. 
A person certainly has a need in the landscape, as in the image of the land where he/she lives, where, according to Johann Peter Hebel, he/she must be rooted, in order to grow up, blossom and bear fruit [13]. Heidegger understood thinking as a metaphor for the path, which runs through the landscape crossed by a wanderer. The landscape appears to us as the text that needs to be constantly read and rethought. The creative landscape involves different ways of ideas about the earth spaces and different ways of their interpretation. The landscape could easily acquire repressive features, leaving a person less and less space for life and freedom.

In connection with the above, the attempts to revive in May 2015 a national holiday "Spring" in the city of Tyumen are of great interest. The Tyumen Contemporary Laboratory, which set itself this task, is an informal organization engaged in the development of new brands for the Tyumen city, which is known in the world solely as a "place of oil and gas storage". It should be noted that the Tyumen Contemporary Laboratory and the Charity Development Fund of the Tyumen City undertook to revive not some official holiday, but a popular holiday, which tradition dates back to the very depths of centuries. This holiday is known from the texts of historians and the memoirs of contemporaries. It was very popular before the revolution; it was celebrated on the ninth Friday after Easter; it was associated with the worship of a healing spring. Perhaps, this refers to a variant of the Indo-European cult of springs. As for the holiday "Spring", we see constant updating of the tradition (or a text rewriting tradition): today's holiday is actually the "Fourth Spring". It was closed for various reasons four times, and four times it revived. The festival is held in the Gorodishche Logue - somewhere in this place before the arrival of Ermak there was a mysterious city Chimgy Tura, whose invisible remains are buried in the heart of the modern Tyumen city. However, this "silent figure" of the modern urban landscape has the most significant impact on its interpretation. For many years, the city's ravines have been a wild, chthonic part of the Tyumen city, out of the urban space, and only in recent years residents began to think about the cultural development of the city's ravines. A complex and multidimensional problem of the revival of the national holiday has demanded to bring to the organization of the festival the musicians and writers, whose works mentioned the "places of power", the problem of geopoezis, internal cartography and creative rethinking of landscapes. The festival organizers have found it correct to create a special communicative situation, when all sorts of psychological, cultural and landscape factors correlate.

The activities of the Tyumen Club of Careless Travelers (Club of Emotional Journeys), an initiative group, created several years ago, can be noted as one of the significant geopoetic projects. Sometimes journeys to the nearby towns and villages organized by this club resembled psycho-geographic drifts; sometimes - eco-tourism activities; sometimes - minor regional natural history expeditions with the aim to find historical places (Myron Galanin's grave, Ermak's grave, etc.). However, writing reports, in which the main focus was on capturing and describing the subjective importance and beauty, was a compulsory requirement of participation in journeys. Thus, there was an intellectual and aesthetic development of the landscape, its intimization, overcoming the stereotypical and mechanical perception of one's own existence. According to Fedor Karandey, a participant of these projects: "New ways are formed to talk about our native country as a space of emotional and active attachment to the cities and villages, a space where a new language is formed, for which the relationship of aggression and defense is of no importance, a language of the joint happy life, labor, contemplation and love" [14]. 


\section{DISCUSSION}

Taking all the aforesaid into consideration, it should be noted that the projects under review are similar to many other spatial practices that are developing today in different cities not only in the country, but all over the world. Listing up similar projects would take up too much space in the article. It seems that they are not accidental, but they express some important trend of forming the new geospatial discourse. All of them are geopoetic, since they gravitate toward the performance, happening and street-art in the enlarged sense of the term. All of them are oriented to a new experience of in-growth and empathy for the landscape; they are all meditative to some extent. This is shown in travelogues, reflecting the difficult experience of the "traveling art", that are very close in meaning to the ideas expressed by Kaganskiy in his lectures [15]. All of them are less likely focused on meta-narratives and expect "poetic discoveries" in the familiar and ordinary landscapes. Not passive landscape watching (staring), but the work of admiring the landscape, when this process involves the eyes, mind and heart -apparently, this is the main feature of the projects mentioned in the article.

\section{CONCLUSION}

Let us make some conclusions. 1) The space is likely to be the most important capital of the close, clumped 21st century. The desire to get out into the expanse was inherent in man at all times, but soon it will be realized particularly acute. As the philosophers of the twentieth century said: the expanse implies an event, while the eventfulness composes the life. 2) In the same way that in the anthropology of art the vision and viewing are distinguished (the vision is passive, viewing is - it implies the perception of the image, the creation of meaning of the image, etc.); people will learn to distinguish between simple walking and wandering full of meaning. For Mayakovsky, walking created a rhythm of poetry. In the book "Pilgrim's Frank Replies to His Spiritual Father", the steps set pace to the reading of the Jesus Prayer. For Kenneth White, setting off on a journey meant "leaving for the leaves and the wind", escaping from all attachments. In our opinion, this point in the culture will be intensified. Traversing the space can be perceived as the art. It is most likely that in the future we will witness the development of the art of reading of the space, landscapes, which are filled with a variety of relational systems. Traversing the space may serve as therapy. Traversing the space can help get rid of the power of hypnosis, which, in Foucault's opinion, can easily charm us. The personal attitude to the space implies that a person opens the space in its uncertainty, unpredictability and life-changing character. 3) The Schweitzer's idea of "reverence for life" can expand to the idea of "reverence for the space". The ethics of reverence for the space can be implemented only in the individual choice of the personal attitude to the space and the personal development of the space. Certainly, reverence for the space will be also manifested in the humanization of modern architecture, which is currently notable for its exceptional functionality. Reverence for the space is undoubtedly related to the dramatization of man's attitude to the space, when both intellectual efforts and feelings play an important role. It is likely that our attitude to the space at the new level will include an axiological dimension, as it was in ancient times, when the space had a center ("the axis of the world") and a person distinguished the areas of space with the greatest existential and cosmic nature. 4) The problem of the search by a person for his/her place in the space will be updated, whereas in the context of globalization each person will possess the treasury of the world space. Due to the humanization of the space, it will become for the man something more than an empty container of material objects. In fact, the destruction of consciousness of the industrial era ("industry-reality" in the terminology of Toffler) will be rather logically associated with the elimination of leveling of the space and time by the 
society, with the return to a person's own sensorium and one's own original being (in the Jungian tradition - I-turn from a person to the deep Self).

\section{REFERENCES:}

1. Isaev, B.A. (2011). Geopolitika klassicheskaya i geopolitika sovremennaya [Classic Geopolitics and Contemporary Geopolitics]. Polis, 2, 69-85.

2. Journal of Social \& Cultural Geography, 12. (2010).

3. Duncan, J.S., Johnson, N.C., \& Schein, R.H. (Eds.). (2004). Companion to Cultural Geography. Wiley.

4. Kaufman, V. (2006). Guy Debord: Revolution in the Service of Poetry. Minneapolis: University of Minnesota Press.

5. Deleuze, G., \& Guattari, F. (1998). Chto takoe filosofiya? [What is Philosophy?] Moscow: Institute of Experimental Sociology; St. Petersburg: Aletheia.

6. Mitin, I. (2008). Mesto kak palimpsest [Location as a Palimpsest]. 6o parallel', 4, 40-45.

7. Certeau, M. de. (2005). Po gorodu peshkom [Walking in the City]. Retrieved November 24, 2016, from http://ecsocman.edu.ru/data/259/440/1218/6-Communitas_2_2005_Certeau.pdf.

8. Sid, I., \& the Group "Poluostrov". (1996). Osnovnoy vopros geopoetiki [The Main Question of Geopoetics]. In Pervaya konferentsiya po geopoetike, Moskva, Krymskiy klub, 24.04.96 [First Conference on Geopoetics, Moscow, the Crimean Club, April 24, 1996]. Retrieved November 24, 2016, from http://liter.net/geopoetics/penin.html.

9. Zinik, Z. (1996). Dve geografii [Two Geographies]. In Pervaya konferentsiya po geopoetike, Moskva, Krymskiy klub, 24.04.96 [First Conference on Geopoetics, Moscow, the Crimean Club, April 24, 1996]. Retrieved November 24, 2016, from http://www.liter.net/geopoetics/zinik.html.

10. Poeticheskiy putevoditel' po gorodam "Kul'turnogo al'yansa" [Poetry Guide for the Cultural Alliance Cities] (p. 12). (2012). Perm: Kul'turnyy al'yans.

11. Poeticheskiy putevoditel' po gorodam "Kul'turnogo al'yansa" [Poetry Guide for the Cultural Alliance Cities] (p. 399). (2012). Perm: Kul'turnyy al'yans..

12. Poeticheskiy putevoditel' po gorodam "Kul'turnogo al'yansa" [Poetry Guide for the Cultural Alliance Cities] (p. 11). (2012). Perm: Kul'turnyy al'yans.

13. Hayden, W. (2002). Metaistoriya: Istoricheskoe voobrazhenie v Evrope 19 veka [Metahistory: Historical Imagination in Europe in the 19th Century] (pp. 50-60). Yekaterinburg: Publishing House of the Urals University.

14. Karandey, F. (2016). O lyubvi k Rodine. Rodnoe i dalekoe: slovo v zashchitu kraevedeniya [On the Love for the Motherland. Native and Distant: A Word in Defense of the Local History]. Retrieved November 24, 2016, from http://gefter.ru/archive/18178.

15. Kaganskiy, V. (2014, June 20). "Mne povezlo obnaruzhivat' lakuny". Interv'yu s Ol'goy Balla ["I Was Lucky to Discover the Lexical Gaps". The Interview with Olga Balla]. Chastnyy korrespondent. 